\title{
PRIMARY JURISDICTION: THE RULE AND ITS RATIONALIZATIONS
}

\author{
ISRAEL GONVISSER $\dot{T}$
}

Accretion of the administrative process is one of the phenomena of our times. Delegations of executive and legislative authority are steadily expanding the administrative domain, often into regions previously occupied only by the judiciary. A resulting problem has been to redefine the boundaries of judicial jurisdiction where it is abutted or encroached upon by administrative jurisdiction.

A judicial contribution to this redefinition has been the rule of exclusive primary administrative jurisdiction, which removes formerly justiciable issues from the province of the courts and relegates them to administrative adjudication. Like the administrative process of which it is so important a part, the rule is a dynamic and expanding one. In its earliest application ${ }^{1}$ it made the lawfulness of a past railroad rate a matter for exclusive initial administrative jurisdiction. In its later development it has extended the scope of administrative competence to include what in effect amounts to the granting or withholding of immunity from the antitrust laws. ${ }^{2}$

There is no question but that the rule serves a useful purpose-to prevent premature or undue judicial interference with the administrative process. Whether the rule serves this purpose effectively is another question-and one that is being debated. ${ }^{3}$ But debate about proper application cannot be meaningful out of the context of the scheme of administrative regulation of which the rule is an adjunct. And unfortunately, the organic relationship between the rule of primary jurisdiction and the administrative process as a whole has too often been obscured by the rationalizations that have marked the rule's birth and growth.

As a result, the rule has been applied in curious ways that reflect little understanding of its essential purpose. That any rule should never be misapplied is, of course, beyond reasonable expectation. Allowance must be made for hard cases and human shortcomings. But misapplications of this rule, beyond normal expectancy, must inevitably spring from the sophisms with which the literature of primary jurisdiction abounds. It is the purpose of this

$\dagger$ Member of the District of Columbia and New York Bars.

1. Texas \& Pac. Ry. v. Abilene Cotton Oil Co., 204 U.S. 426 (1907).

2. See Seatrain Lines, Inc. v. Pennsylvania R.R., 207 F.2d 255 (3d Cir.), cert. deviied, 345 U.S. 916 (1953), discussed in text at pp. 332-35 infra.

3. Professor Louis B. Schwartz thinks the rule has been overextended: Legal Restriction of Competition in the Regulated Industries: an Abdication of Judicial Responsibility, 67 HARv. L. REv. 436 (1954) ; Robert B. von Mehren thinks not: The Antitrust Laws and Regulated Industries: the Doctrine of Primary Jutrisdiction, 67 id. at 929. See also Jaffe, Prinlary Jurisdiction Reconsidered. The Anti-trust Laws, 102 U. PA. L. REv. 577 (1954). 
paper to dissipate some of the fog of misunderstanding that has prevented realistic appreciation and application of the rule. To start, we must go back half a century to the moment when the rule, conceived in error, was launched on its questionable career.

\section{Genesis}

The primary jurisdiction rule, a sesame in reverse, was first invoked in Texas \& Pacific Ry. v. Abilene Cotton Oil Co.* to lock a judicial door that the applicable statute had held open. It was the creation of Justice White who, speaking for a unanimous Supreme Court, held that under what is now known as the Interstate Commerce Act a shipper seeking reparations from a railroad for excessive freight charges must "primarily invoke redress through the Interstate Commerce Commission."

This ruling, divesting the courts of jurisdiction they had long exercised," is a classic of judicial legislation. It did violence to the plain statutory language and purpose, ignored the legislative history and rested upon reasoning mainly notable for its comfortable insulation from reality. To see where the Abilene decision went astray, we must first examine the Act to Regulate Commerce, ${ }^{7}$ since the case turned entirely upon construction of that statute.

\section{The Act to Regulate Commerce}

As originally enacted, the Act created the Interstate Commerce Commission but gave it no power to establish rates for the future, ${ }^{8}$ except insofar as a rate for the future, as a practical matter, necessarily resulted from an order directing the carrier to desist from charging a rate found by the Commission to have been invalid in the past. Carriers had to publish their rates and file them with the Commission. They were required to give ten days' public notice in advance of any increase in rates but could make decreases without advance notice. Deviations from published rates were otherwise prohibited. ${ }^{0}$ The Act required rates to be reasonable and just; outlawed rebates, discriminations, preferences and advantages; and subjected the carriers to liability for damages to persons injured by violations of the Act, as well as to criminal prosecution and fines therefor.

Upon receipt of a complaint, which could be filed by any person or organization, the Commission was directed to forward a statement of the charges to

4. 204 U.S. 426 (1907).

5. Id. at 448 .

6. The Court said, "Without going into detail, it may not be doubted that at common law, where a carrier refused to receive goods offered for carriage except upon the payment of an unreasonable sum, the shipper had a right of action in damages." Id. at 436.

7. C. 104,24 Stat. 379 (1887).

8. This power was supplied by the Act of June 29,1906, c. $3591, \S 4,34$ STar. 589 .

9. The Act of March 2,1889, required three days' advance notice of a rate decrease. C. $382, \S 6,25$ Stat. 856 . By the Act of June 29,1906 , thirty days' advance notice of any change in rates was required, but the Commission was authorized to allow changes on shorter notice. C. 3591, § 2, 34 STAт. 586 . 
the carrier. If the carrier made reparation it was relieved of liability for that violation. If the carrier did not satisfy the complaint or there was reasonable ground for investigating, the Commission was to conduct an investigation and make a written report containing findings which were to be deemed prima facie evidence, as to the facts found, in all subsequent judicial proceedings. If the Commission found the carrier guilty of a violation it could require the carrier to cease and desist, to make reparation, or both.

Section 16 of the Act made it the duty of the Commission and the right of any person interested, in the event of the carrier's failure to "obey any lawful order or requirement of the Commission,"10 to apply to the United States circuit court (not to be confused with the circuit court of appeals) sitting in equity in the judicial district in which the carrier had its principal office or in which the violation or disobedience of the order occurred. If the court found that the lawful order of the Commission had been disobeyed it could award damages and issue a writ of injunction or other proper process. But there was no provision for resort to court by the complainant in the event of a Commission finding in favor of the carrier.

Two sections of the Act secured for the courts, in addition to the jurisdiction granted in section 16, original jurisdiction of certain suits within the scope of the Act. Section 9 provided in part:

"That any person or persons claiming to be damaged by any common carrier subject to the provisions of this act may either make complaint to the Commission as hereinafter provided for, or may bring suit in his or their own behalf for the recovery of the damages for which such common carrier may be liable under the provisions of this act, in any district or circuit court of the United States of competent jurisdiction; but such person or persons shall not have the right to pursue both of said remedies, and must in each case elect which one of the two methods of procedure herein provided for he or they will adopt. . . ."11

And section 22 expressly stated that "nothing in this act contained shall in any way abridge or alter the remedies now existing at common law or by statute, but the provisions of this act are in addition to such remedies. . .."12

The history of the Act leaves no doubt that the language of sections 9 and 22 was a plain statement of an unequivocal legislative intention that the courts should have original jurisdiction of some matters that might also be in the Commission's province. When first introduced in Congress in 1886, the bill ${ }^{13}$ did not contain the provisions of section 9 which spelled out the alternative judicial and administrative remedies, though it did include the provision preserving common law and statutory remedies then in existence. Yet Senator Cullom, Chairman of the Select Committee on Interstate Commerce and the man whose name the bill bore, told the Senate:

10. Act to Regulate Commerce, c. 104, § 16, 24 STAT. 384 (1887).

11. Act to Regulate Commerce, c. 104, § 9, 24 Stat. 382 (1887).

12. Act to Regulate Commerce, c. 104, \$22, 24 Stat. 387 (1887).

13. S. 1532, 49th Cong., 1st Sess. (1886). 
"Under the terms of the bill no one is obliged to appeal to the commission, and two courses are open to anyone who may be aggrieved by the violation of any one of these general provisions which I have mentioned. He is simply obliged to elect which course he will adopt, and may at his own pleasure either bring suit in the courts on his own account for the recovery of overcharges or damages, or he may ask the commission to arbitrate the controversy, and, if necessary, to investigate his complaint, the advantage of the latter course being that in the event of a favorable finding by the commission his evidence is collected for him without exexpense to himself, and he can if it becomes necessary go into court with a prima facie case already established."14

After the bill had been put into its final form by a Senate-House conference committee, Representative Crisp of the committee reported to the House:

"Mr. Speaker, we do not drive the complainant to the Railroad Commission. If he chooses to go there he has the right to go and invoke this power which is created by the Government for his protection; but if he prefers, for any reason, to go to the courts of the country, they are open to him. The same judge who passes upon his rights of property, his rights of life and liberty, will there pass upon his rights in his dealings with the railroads.

“....

" $\mathrm{He}$ can go to the commission, but if he is one of those who, either from suspicion or for any other reason, believes that this commission will not do right, then he can go into court and file his suit and have it tried as every other case is tried. . . ."15

Throughout the protracted debate the construction given by Senator Cullom and Representative Crisp to the provisions preserving the judicial forum for reparation suits was never challenged.

\section{The Abilene Case}

The Abilene Company attempted to use the common law remedy preserved by Congress. Without resorting to the Interstate Commerce Commission, it brought suit in a Texas state court to recover damages from the Texas and Pacific Railway for allegedly excessive charges for the transportation of freight. The state court, finding the rate unreasonable and excessive, nevertheless held that since the rate had been filed with the Interstate Commerce Commission it was the rate "established under the interstate commerce law," and gave judgment for the defendant. ${ }^{16}$

The Texas Court of Civil Appeals reversed.17 It stated the issue as "whether in a state court a shipper in cases of interstate carriage can, by the principles of the common law, be accorded relief from unjust and unreasonable freight rates extracted from him, or shall relief in such cases be denied merely

14. 17 Cong. Rec. 3471 (1886).

15. $18 \mathrm{id}$. at 784 (1887).

16. See Texas \& Pac. Ry. v. Abilene Cotton Oil Co., 204 U.S. 426, 431-32 (1907).

17. Abilene Cotton Oil Co. v. Texas \& Pac. Ry., 85 S.W. 1052 (Tex. Civ. App. 1905 ). 
because such unreasonable rate has been filed and promulgated by the carrier under the interstate commerce act?"18 The court found the answer in the common law right of action which it ruled had been preserved by the Act. ${ }^{19}$

The United States Supreme Court posited its reversal upon what it deemed to have been the legislative intent as demonstrated by the following propositions:

1. The Act "made it unlawful [for the carrier] to depart from the rates in the established schedules until the same were changed as authorized by the act. . . ."20

2. The Act showed "an indissoluble unity between the provision for the establishment and maintenance of rates until corrected in accordance with the statute and the prohibitions against preferences and discrimination."21

3. If "the standard of rates fixed in the mode provided by the statute could be treated on the complaint of a shipper by a court and jury as unreasonable, without reference to prior action by the Commission, finding the established rate to be unreasonable and ordering the carrier to desist in the future from violating the act, it would come to pass that a shipper might obtain relief upon the basis that the established rate was unreasonable, in the opinion of a court and jury, and thus such shipper would receive a preference or discrimination not enjoyed by those against whom the schedule of rates was continued to be enforced."22

4. Existence of original jurisdiction in the courts would afford "a ready means by which, through collusive proceedings, the wrongs which the statute was intended to remedy could be successfully inflicted." ${ }^{23}$

5. If the "power existed in both courts and the Commission to originally hear complaints on this subject, ... the established schedule might be found reasonable by the Commission in the first instance and unreasonable by a court acting originally, and thus a conflict would arise which would render the enforcement of the act impossible," since the Commission would thus be made incapable of performing its function of bringing about uniform rates. ${ }^{24}$

6. Section 9 could not have authorized the courts to have original jurisdiction of reparation suits since the section "contemplates only a decree in favor of the individual complainant, redressing the particular wrong asserted to have been done, and does not embrace the power to . . . command a correction of the established schedules," which only the Commission has; consequently, the section "must be confined to redress of such wrongs as can, consistently with the context of the act, be redressed by courts without previous action by the Commission, and, therefore, does not imply the power in a court

18. Id. at 1053.

19. Id. at $1054-55$.

20. Texas \& Pac. Ry. v. Abilene Cotton Oil Co., 204 U.S. 426, 437 (1907).

21. Id. at 440 .

22. Ibid.

23. Id. at 441.

24. Ibid. 
to primarily hear complaints concerning wrongs of the character of the one here complained of."25

7. Similarly, section 22 could not be construed as perpetuating "a common law right, the continued existence of which would be absolutely inconsistent with the provisions of the act. ... The clause is concerned alone with rights recognized in or duties imposed by the act, and the manifest purpose of the provision in question was to make plain the intention that any specific remedy given by the act should be regarded as cumulative, when other appropriate common law or statutory remedies existed for the redress of the particular grievance or wrong dealt with in the act."26

Having noted the principle of statutory construction that "repeals by implication are not favored," 27 and having rejected an argument that harm would result from depriving the courts of jurisdiction as "an argument of inconvenience which assails the wisdom of the legislation or its efficiency and affords no justification for so interpreting the statute as to destroy it," 28 the Court laid down the rule "that a shipper seeking reparation predicated upon the unreasonableness of the established rate must, under the act to regulate commerce, primarily invoke redress through the Interstate Commerce Commission, which body alone is vested with power originally to entertain proceedings for the alteration of an established schedule, because the rates fixed therein are unreasonable. . . ."29

The major emphasis of the reasoning was upon the aim of uniformity. The Court maintained that discriminations would inevitably ensue unless the holding that a rate had been unlawful and must be desisted from in the future was uniformly applied, and that this could be achieved only by requiring resort to the Commission in the first instance.

\section{Abilene Analyzed}

Both the assumptions and the logic of the Abilene decision are open to question. To begin with, the likelihood of original actions at law occurring in sufficient numbers to threaten the success of Commission regulation seems to have been considerably exaggerated. Senator Cullom, explaining why his committee had deemed it desirable to provide an alternative to the common law remedy, read from the committee report the following statement by Chairman Kernan of the New York Commission:

" 'Assuredly there have been and do exist unreasonable rates and unjust discriminations. This much will be admitted by all; it will not be denied even by any carrier. Why, then, have not the courts enjoined the continuance of the wrongs and enforced the payment of damages? Why, again, is it that substantially no such suits ever have been brought and that so few decisions in this country exist? It is not because of

\footnotetext{
25. Id. at 442.

26. Id. at $446-47$.

27. Id. at 437 .

28. Id. at 447 .

29. Id. at 448 .
} 
defects in the law or in the constitution of the courts; but it is because the subject is one which neither client nor lawyer, judge nor jury, can unravel or deal with intelligently within the compass of an ordinary trial and with such knowledge of the matter as men generally well educated possess. . . . As the onus is upon the complainant, add to his difficulties the fact that his adversary has nearly all the evidence in his possession, locked up in books and in the memory and intelligence of experts who have made the subject their study. The expense involved, the uncertainty to be faced, and the difficulties to be overcome in an ordinary suit at law have made that remedy obsolete and useless.' "30

Exaggeration of the magnitude of the problem, however, was a lesser error. More serious was the significance the Court attached to the statutory requirement that rates be adhered to unless and until changed as "authorized by the act." 31 It stated that to hold that there was original jurisdiction in the courts "would necessitate the holding that a cause of action in favor of a shipper arose from the failure of the carrier to make an agreement, when, if the agreement had been made, both the carrier and the shipper would have been guilty of a criminal offense and the agreement would have been so absolutely void as to be impossible of enforcement."32 This was less than a fair statement. Actually, all that the Act imposed in this connection was a publication and filing requirement that left the railroad otherwise free to change its rates. Nothing in the Act prevented alteration of rates at the time of the overcharge so long as the statutory notice was given. ${ }^{33}$ The issue in a suit such as the Abilene Company's was not whether the carrier could or should have charged rates other than those published, but rather whether the rates as published were excessive.

The matter of adherence to published rates stood at the threshhold of the uniformity argument. The Court was no doubt correct in reading the Act as seeking to establish and enforce uniformity of rates. ${ }^{34}$ But it should be

30. 17 Cosv. Rec. 3474 (1886).

31. See text at note 20 supra.

32. Texas \& Pac. Ry. v. Abilene Cotton Oil Co., 204 U.S. 426, 445 (1907). The statement that the shipper would have been guilty of a criminal offense presumably referred to the Elkins Act of Feb. 19, 1903, c. 708, 32 Star. 847. But the cause of action arose in 1901, two years before that Act became law.

33. See Armour Packing Co. v. United States, 209 U.S. 56 (1907), which affirmed the conviction of a shipper under the Elkins Act, see note 32 supra, for paying a railroad, after the railroad had published an increase in rates, the rate contracted for pursuant to the schedule in effect at the time of the contract.

And in ICC v. Chicago G.W. Ry., 209 U.S. 108 (1908), the circuit court had set aside a Commission order directing the carrier to desist from charging a rate found to have been unlawful. Affirming, the Supreme Court said:

"It must be remembered that railroads are the private property of their owners.... [T] he act to regulate commerce leaves common carriers, as they were at common law, free to make special rates looking to the increase of their business, to classify their traffic, to adjust and apportion their rates . . . and generally to manage their important interests upon the same principles which are regarded as sound and adopted in other trades and pursuits." Id. at 118-19.

34. Texas \& Pac. Ry. v. Abilene Cotton Oil Co., 204 U.S. 426, 441 (1907). 
noted initially that uniformity of reparations was another matter, and one with which the Act was not concerned. The fact that one shipper received greater or lesser reparations than another was not tantamount to a preference of the sort that the Act was intended to prevent, for it created no real competitive advantage. There could be such an advantage only if a shipper knew in advance that his freight cost would be less than that of his competitors and thus could sell at a lower price. But he obviously could not set his prices on the mere speculation that he would be awarded reparations. It may have been, of course, that the Court was harboring an unexpressed concern for the plight of the railroads. These, it is true, were subject under the Act to the risk of different determinations in different forums. But so had they been theretofore, when they could have been sued in various courts, both federal and state. And the plain purpose of the Act was not to improve the situation of the railroads but to curb their excesses and protect the shippers. Uniformity of reparations was, in sum, no more important than uniformity of damages in negligence cases.

Uniformity of rates, on the other hand, was of the greatest significance, and the Court feared that diversity of reparation awards would make uniformity of rates impossible. Prior to 1906 the Commission, like the courts, was without power to establish rates for the future; it could only declare a rate to have been unlawful in the past. ${ }^{35}$ The Court saw in the coupling of this power with the authority to issue a cease and desist order an equivalent for the originally withheld authority to set rates for the future, ${ }^{30}$ but one that would be greatly weakened by the existence of nearly parallel authority in the courts.

However, the Act of June 29, 1906, empowering the Commission to establish rates for the future at the instance of shipper, carrier or others, ${ }^{37}$ removed the basis for the Court's apprehension that varying reparation awards would prevent uniformity of rates. For the carrier or other interested parties could apply to the Commission for establishment of a rate for the future. This rate would come as close to being conclusive and insuring uniformity as was possible under the Act. Section 15, as amended, provided that "orders of the Commission, except orders for the payment of money, . . . shall continue in force for such period of time, not exceeding two years, as shall be prescribed in the order of the Commission, unless the same shall be suspended or modified or set aside by the Commission or be suspended or set aside by a court of competent jurisdiction." 38 This amendment, permitting an approximation of uniformity to be achieved through the rate making authority conferred upon the Commission, was enacted five years after the cause of action in the

35. Cincinnati, N.O. \& T. Pac. Ry. v. ICC, 162 U.S. 184, 196-97 (1895); see Arizona Grocery v. Atchison Ry., 284 U.S. 370, 385 (1932).

36. Texas \& Pac. Ry. v. Abilene Cotton Oil Co., 204 U.S. 426, 441 (1907).

37. C. $3591, \S 4,34$ STAt. 589.

38. Act of June 29,1906, c. $3591, \$ 4,34$ STAT. 589. The Commission could not award reparations if it subsequently held a rate so established to have been unreasonable. Arizona Grocery v. Atchison Ry., 284 U.S. 370 (1932). 
Abilene case arose. But it was law when the case was decided, and part of the context of the case.

Furthermore, Justice White's assumption, that with respect to rates not prescribed by the Commission uniformity could be achieved by primary administrative jurisdiction, wholly overlooked the threat of variation that lay in the continued existence under the Act of secondary jurisdiction in the courts. Under section 16 of the Act, if the carrier failed to comply with the Commission's order a trial of the issue could be had in the circuit court, which could award a money judgment or other relief. ${ }^{39}$ When more than twenty dollars was involved, the seventh amendment to the Constitution gave the parties the right to trial by a jury. ${ }^{40}$ And this meant that a determination by the Commission that a past rate had been unreasonable was subject to overturn by court and jury, as was the Commission finding as to the amount of the overcharge and, consequently, what was a reasonable rate. ${ }^{41}$ The report of the Commission would be prima facie evidence of the facts found, but this evidence could be rebutted. The relative functions of the Commission and the courts in this respect had been described as follows:

"The suit in this court is, under the provisions of the act, an original and independent proceeding, in which the commission's report is made prima facie evidence of the matters or facts therein stated. It is clear that this court is not confined to a mere re-examination of the case as heard and reported by the commission, but hears and determines the cause de novo, upon proper pleadings and proofs, the latter including not only the prima facic facts reported by the commission, but all such other and further testimony as either party may introduce, bearing upon the matters in controversy." 42

And in another case the Supreme Court recognized the right, though it chided the railroad for abusing the right, of producing before the court evidence not offered to the Commission. ${ }^{43}$

39. Act to Regulate Commerce, c. 104, § 16, 24 STAт. 38485 (1887).

40. Before the Court made the Commission the sole depository of jurisdiction of reparation claims, the latter body had decided that its jurisdiction, far from being exclusive, was nonexistent. The original Act of 1887 made no provision for jury trial of a complaint based upon a Commission reparation order. On the contrary, the circuit court was to determine the matter as a court of equity. But the Commission declined to award reparations because to do so would violate the seventh amendment. Report of Interstate Commerce Commission, Dec. 1, 1887, 1 I.C.C. 297-99. This Report also stated that the Commission had "not discovered in the statute a purpose to confer upon it the general power to award damages in the cases of which it may take cognizance. The failure to provide in terms for a judgment and execution is strong negative testimony against such a purpose. . . Id. at 298. The Act of March 2, 1889, c. 382, $\$ 5,25$ StAT. 860-61, amended $\$ 16$ to make jury trials available in such cases.

41. The court or jury could reduce a reparation award by the Commission. Pennsylvania R.R. v. Minds, 250 U.S. 368 (1919). It could not, however, give a judgment in excess of the award. Baltimore \& O.R.R. v. Brady, 288 U.S. 448 (1933).

42. Kentucky \& Indiana Bridge Co. v. Louisville \& N.R.R. 37 Fed. 567, 614 (C.C. Ty. 1889), appeal dismissed, 149 U.S. 777 (1893); see Baer Bros. Mercantile Co. v. Denver \& R.G.R.R., 200 Fed. 614 (D. Colo. 1912), aff'd, 209 Fed. 577 (8th Cir. 1913).

43. Cincinnati, N.O. \& T. Pac. Ry. v. ICC, 162 U.S. 184, 196 (1895). 
In these circumstances the Court in the Abilene case clearly exaggerated the extent to which closing the judicial door to damage suits would result in uniformity of decision as to either reparations or the unreasonableness of past rates. Uniformity would be assured only in findings that past rates had been reasonable, since, as will be discussed shortly, there was no recourse to judicial review of such determinations. ${ }^{44}$ In any event, the Court's conclusion that the "standard would fluctuate and vary, dependent upon the divergent conclusions reached as to reasonableness by the various courts," 45 would apply almost as fully to cases in which the Commission made the primary determination as to those in which the courts might have done so.

The Court in Abilene asserted that primary judicial determination would affect only the litigating parties whereas the administrative order would have greater reach. ${ }^{46}$ This argument has some merit, but the Court seems to have overlooked or ignored the following provision of the Act of February 19, 1903:

"Sec. 2. That in any proceeding for the enforcement of the provisions of the statutes relating to interstate commerce, whether such proceedings be instituted before the Interstate Commerce Commission or be begun originally in any circuit court of the United States, it shall be lawful to include as parties, in addition to the carrier, all persons interested in or affected by the rate, regulation, or practice under consideration, and inquiries, investigations, orders, and decrees may be made with reference to and against such additional parties in the same manner, to the same extent, and subject to the same provisions as are or shall be authorized by law with respect to carriers." 47

It was thus possible in a single adjudication to bind a substantial number of parties in interest and so reduce the likelihood of divergent determinations. ${ }^{48}$

In sum, the principal thrust of the Abilene opinion-that primary administrative jurisdiction would assure uniformity of regulation, and concurrent jurisdiction prevent it-was awry. The slight marginal gain in uniformity seems hardly sufficient to justify overturning, in the name of the general congressional scheme, the explicitly declared intention of Congress. This intention, that the courts should retain concurrent jurisdiction, had been expressed in sections 9 and 22. The Court avoided the plain meaning of these sections, and read them to refer to suits other than for reparations, in order

44. This is no longer so, however. See note 60 infra.

45. Texas \& Pac. Ry. v. Abilene Cotton Oil Co., 204 U.S. 426, 440 (1907).

46. See text at note 25 supra.

47. Act of Feb. 19, 1903, c. 708, § 2, 32 Stat. 848.

48. This section, although not referred to, seems to have been the basis for bringing in additional parties in Baltimore \& O.R.R. v. Pitcairn Coal Co., 215 U.S. 481 (1910). This was a petition in mandamus by the operator of a coal mine, charging discrimination by the railroad in the distribution of coal cars. Six coal companies that were allegedly receiving preferences were joined as defendants, as were thirty-one independent coal companies that were presumably suffering discrimination. The petition, granted below, was ordered dismissed on the ground that the complaint should have been made to the Commission in the first instance. 
to square them with its premise of uniformity. When the premise falls, so must the strained statutory interpretation built upon it.

Underlying Justice White's construction of the statute was, it seems, the feeling that concurrent jurisdiction, whether intended by Congress or not, would be entirely unworkable. In a later case he elaborated this, addressing himself to the question whether Commission or courts would prevail if, having concurrent jurisdiction, they made conflicting determinations. He concluded that if both prevailed,

"then discrimination and preference would result from the very prevalence of the two methods of procedure. If, on the contrary, the commission was bound to follow the previous action of the courts, then it is apparent that its power to perform its administrative functions would be curtailed, if not destroyed. On the other hand, if the action of the commission was to prevail, then the function exercised by the court would not have been judicial in character, since its final conclusion would be susceptible of being set aside by the action of a mere administrative body." ${ }^{9}$

This reasoning overlooked a number of considerations. In the first place, neither Commission nor court had to prevail. The awards of both could stand. As already noted, uniformity of damages in this area is no more important than uniformity of any other kind of damages. And diversity of damages is inherent in our judicial system. In the second place, neither courts nor Commission would totally prevail even under the Act as interpreted in Abilene. Upon determination by the Commission that the carrier had violated the Act, the complainant would in any event have the choice of asking the Commission to award reparations or bringing a law suit for damages, ${ }^{50}$ so that concurrent jurisdiction persisted. And even when the Commission took initial jurisdiction, its findings of fact could be overturned by court or jury and its conclusions of law by the court. As to the latter the courts necessarily had to prevail, and the Commission would have had to accommodate its own views of the law to those of the courts whether handed down as a matter of initial jurisdiction or on review. And on the other hand, the courts' determinations were still in a sense "susceptible of being set aside by the action of a mere administrative body," "ar since even after the court had made a determination in an enforcement proceeding that a given rate was reasonable, the Commission could thereafter set the rate at any amount it found appropriate. And review of such an order other than for the payment of money would not entail de novo trial but would be limited to the question whether "the order was regularly made and duly served."

Actually, the problem with which Justice White was concerned was one

49. Baltimore \& O.R.R. v. Pitcairn Coal Co., 215 U.S. 481,495 (1910). As mentioned in note 48 supra, this case involved alleged discrimination in the distribution of coal cars.

50. Terminal Warehouse v. Pennsylvania R.R., 297 U.S. 500, 508 (1936); Pennsylvania R.R. v. Clark Coal Co., 238 U.S. 456, 470 (1915).

51. See text at note 49 sulpra.

52. Act of June 29,1906, c. $3591, \S 5,34$ STar. 591. 
commonly encountered and overcome where different forums have concurrent jurisdiction. In time divergences are drawn together by acts of Congress, appeals, and application of rules of comity. ${ }^{53}$ Joinder of parties might have been utilized to limit the number of cases from which differences could have resulted. ${ }^{54}$ And evidence gathered by the Commission could have been used in cases brought into court in the first instance. ${ }^{55}$ Thus, a judicialadministrative modus vivendi could have been achieved within the framework of the Act as written, by the use of tools that a resourceful judiciary has generally been capable of shaping to its needs.

Finally, the Court's argument in Abilene that collusive evasion of the prohibition against preferences and rebates would be easier in the judicial than in the administrative forum is a makeweight, and a light one. The contrary fact was that for those who were ready to run the risk of collusive evasion, the Commission proceeding was a convenient means for doing so. Section 13 provided that upon receipt of a petition the Commission should forward a statement of charges to the carrier "who shall be called upon to satisfy the complaint or to answer the same in writing. . . . If such common carrier, within the time specified, shall make reparation for the injury alleged to have been done, said carrier shall be relieved of liability to the complainant only for the particular violation of law thus complained of." 56 At least so far as the mechanics were concerned, no serious difficulties stood in the way of arranging for a rebate by having the shipper make a complaint to the Commission which the carrier would promptly satisfy.

One further point must be noted. The Abilene decision withdrew the right to a jury trial which the seventh amendment was thought to have preserved. ${ }^{67}$ The opinion recognized that unreasonable charges by a common carrier had been actionable at common law, ${ }^{5 s}$ but failed to recognize that sections 9 and 22 of the Act safeguarded the complainant's right to jury trial by authorizing reparation suits in federal courts and similar suits in state courts. Under the original statutory scheme, if the shipper wanted a jury trial he could bypass the Commission; and the carrier could have a jury trial regardless of the

53. "This court has ascribed to them [Commission findings] the strength due to the judgments of a tribunal appointed by law and informed by experience." Illinois Cent. R.R. v. ICC, 206 U.S. 441,454 (1907).

54. See text at notes 45-48 supra.

55. The Act of June 29, 1906, c. 3591, § 5, 34 SrAT. 592, amended section 16 so as to provide:

"The copies of schedules and tariffs of rates, fares, and charges, and of all contracts, agreements, or arrangements between common carriers filed with the Commission as herein provided, and the statistics, tables, and figures contained in the annual reports of carriers made to the Commission,... shall be received as prima facie evidence of what they purport to be for the purpose of investigations by the Commission and in all judicial proceedings. ..."

56. Act to Regulate Commerce, c. 104, § 13, 24 Star. 384 (1887).

57. See note 40 supra.

58. Texas \& Pac. Ry. v. Abilene Catton Oil Co., 204 U.S. 426, 436 (1907). 
forum of primary resort.59 Under the scheme as altered by the Abilene decision, if the Commission found in favor of the shipper, he could still have his suit to enforce the Commission's order tried by jury, but that right was impaired by the fact that the jury could not make an award greater than that of the Commission. And if the Commission found the rate at issue to have been reasonable the shipper was without recourse to the courts. ${ }^{60}$ In that event, denial of access to the courts in the first instance was denial of the right to trial by jury. ${ }^{61}$

Thus the remarkable birth of the remarkable rule of primary jurisdiction. Almost five decades have since elapsed. And still, as if in lingering protest, section 9 of the Act gives courts and Commission concurrent jurisdiction of reparation claims and section 22 preserves pre-existing remedies-both in the identical language, save for changes due to codification, of the original Act of $1887^{\circ 2}$

For all of its dubious origin the rule of primary jurisdiction ${ }^{63}$ became quickly and firmly engrafted on the law, for it answered, however inadequately, the need for a guide in drawing the line between the jurisdiction of the courts and those of the proliferating administrative agencies. But the confusion as to the rule's character and function that attended its birth has haunted its

59. Act of March 2, 1889, c. 382, \$ 5, 25 STAt. $\$ 60$.

60. This is no longer so. The "negative order" doctrine, relied upon in Procter \& Gamble Co. v. United States, 225 U.S. 282 (1912), was laid to rest in Rochester Tel. Corp. v. United States, 307 U.S. 125 (1939).

61. In Baltimore \& O.R.R. v. Brady, 288 U.S. 448,458 (1933), holding that the amount of the Conmission award of reparations was the limit that the complainant could obtain in court, the opinion stated:

"It is to be remembered that, by electing to call on the Commission for the determination of his damages, plaintiff waived his right to maintain an action at law upon his claim. But the carriers made no such election. Undoubtedly it was to the end that they be not denied the right of trial by jury that Congress saved their right to be heard in court upon the merits of claims asserted against them. The right of election given to a claimant reasonably may have been deemed an adequate ground for making the Commission's award final as to him."

But the complainant, under the Abilene decision, had no right of election of the forum in which to establish that the rate, rule or practice had been unlawful, a sine qua non to his right to damages. See Justice Pitney's dissent in Mitchell Coal Co. v. Pennsylvania R.R, 230 U.S. 247, 283 (1913) :

"But is the shipper not entitled to his day in court and to a judicial hearing? Has the Constitution any greater regard for the right of a carrier to trial by jury than it has for the right of a shipper? Conceding, as I do, that Congress could not, because of the Fifth Amendment, make the finding of an administrative body, acting without jury trial, final as against the carrier, I submit, with great respect, that it gives an unconstitutional meaning to the Act if we construe it as depriving the shipper of his remedy without trial by jury."

62. Act to Regulate Commerce, c. 104, 24 Stat. 382,387 (1887), as amended, 49 U.S.C. $\$ \$ 9,22(1952)$.

63. The rule has also been denominated the doctrine of "preliminary resort," or "prior resort." See Davis, Administrative Law 664 (1951). 
development. ${ }^{64}$ The basic error in Abilene was considering as the rule's purpose and its criterion of applicability the deceptive principle of uniformity. Eventually this rationalization was supplemented by another which, unfortunately, was little better.

\section{EXPertise, the New Touchstone}

Justice Brandeis' statement of the rationale of the rule of primary jurisdiction has become classic:

"Whenever a rate, rule or practice is attacked as unreasonable or as unjustly discriminatory, there must be preliminary resort to the Commission. Sometimes this is required because the function being exercised is in its nature administrative in contradistinction to judicial. But ordinarily the determining factor is not the character of the function, but the character of the controverted question and the nature of the enquiry necessary for its solution. To determine what rate, rule or practice shall be deemed reasonable for the future is a legislative or administrative function. To determine whether a shipper has in the past been wronged by the exaction of an unreasonable or discriminatory rate is a judicial function. Preliminary resort to the Commission is required alike in the two classes of cases. It is required because the enquiry is essentially one of fact and of discretion in technical matters; and uniformity can be secured only if its determination is left to the Commission. Moreover, that determination is reached ordinarily upon voluminous and conflicting evidence, for the adequate appreciation of which acquaintance with many

64. An early, perhaps the earliest use of the term primary jurisdiction (Abilenc did not use it) was made in a case that does not seem properly to have involved the rule at all. The majority opinion in ICC v. Chicago, R.I. \& Pac. Ry., 218 U.S. 88, 110 (1910) stated:

"We have also said that the primary jurisdiction is with the Commission, the power of the courts being that of review and is confined in that review to questions of constitutional power and all pertinent questions as to whether the action of the Commission is within the scope of the delegated authority under which it purports to have been made."

The case involved an order issued by the Commission under the 1906 amendment to $\S 15$, see text at note 38 supra, directing the railroad to put into effect for the next two years schedules of reduced freight rates. A circuit court had enjoined enforcement of the Commission's order, but the Supreme Court reversed, holding that the order was within the scope of the Commission's constitutional power and delegated authority, beyond which judicial review could not go.

Unlike Abilene, what was here involved was a legislative act, a rule for the future, not a judicial determination of past invalidity. And, in contrast to the de novo trial available on appeal to the courts from Commission orders in reparation cases, review of the Commission's rate setting orders was limited to inquiry into constitutional power and scope of delegated authority. Cf. Prentis v. Atlantic Coast Line Co., 211 U.S. 210, 226 (1908).

The rule laid down by Abilene divested the courts of jurisdiction they had theretofore possessed. But they had never had jurisdiction to prescribe future rates or to perform other legislative functions. The reference to primary jurisdiction in ICC v. Chicago, R.I. \& Pac. Ry., supra, thus misleadingly suggested that it is a function of the rule to divest the courts of jurisdiction they do not in any event have.

Since the courts do not perform a legislative function to start with, a rule is necessary only to determine when they will not perform their customary judicial functions. It is to the determination of this question that the rule of primary jurisdiction applies. 
intricate facts of transportation is indispensable; and such acquaintance is commonly to be found only in a body of experts." 65

Uniformity was the major thesis of the Abilene opinion. Expertise played no part. The Brandeis statement added expert judgment on technical factual matters as a further justification of the rule of primary jurisdiction-a justification that was not only a statement of purpose but a criterion of applicability as well. As a statement of purpose the suggestion has merit, for the regulatory conmmissioners must inevitably acquire specialized knowledge and experience as a result of the very operation of the primary jurisdiction rule. But as a test of applicability the expertise doctrine is hardly an improvement over the uniformity principle of Abilene.

The trouble is that if the primary jurisdiction rule is to apply whenever there is an expert adjudicating body available, then the rule must have unlimited applicability in the regulated industries. Logically, this leaves the courts no jurisdiction in that area at all.

Has the question been too broadly stated? Justice Brandeis, it is true, spoke of the necessity for administrative expertise as confined to technical matters. But as a limiting factor this has only a specious plausibility. For ours is a complex, technological society. The products of highly developed skills are essential even to the simplest functions of our daily living. And when disputes arise, in our relations of whatever kind, as often as not adjudication involves inquiry into technical matters. Indeed, it is difficult to name a single branch of litigation in which at least a substantial proportion of the cases do not turn upon technical questions of finance, accounting, engineering, medicine, manufacturing methods, distributive patterns, and the like.

For example, to redirect the discussion to the regulated industries, broad supervisory power over safety measures in their industries has been conferred upon the Interstate Commerce Commission ${ }^{66}$ and the Civil Aeronautics Board. ${ }^{67}$ Presumably, then, these agencies now have or in time will develop expertise in an obviously technical matter. If expertise is the test of the rule, there should be primary administrative jurisdiction of the question of negligence in the case of an air crash or train wreck. And since the questions of injury and causal relation involve highly technical medical matters, these too

65. Great No. Ry. v. Merchants Elevator Co., 259 U.S. 285, 291 (1922).

It may be noted that some of the semantic confusion as to the legislative-judicial dichotomy that appeared in the Chicago, Rock Island case, note 64 supra, seems to persist in Justice Brandeis' analysis. Distinguishing initially between the judicial and the legislative functions, he goes on to suggest that both functions are shunted from courts to Commission for the same reason (the reason being that the essence of a question is fact or technical discretion), that the same rule of primary jurisdiction applies to both functions, and inferentially that the courts perform both functions until the rule applies. As pointed out in note 64 supra, the rule is only necessary, and only applicable, when the function in question is a judicial one that would, but for the rule, be exercisable by the courts.

fif. 36 STat. 299 (1910), as amended, 45 U.S.C. $\$ 15$ (1952).

67. 52 Sтлт. 1007 (1938), as amended, 49 U.S.C. $\$ 551$ (1952). 
should be subject to the rule. In short, the qualification that technical matters must be involved is not a limitation of real significance.

The difficulty with expertise as a test for applicability of the rule, therefore, is that it is a compass with an unvarying needle. Turn it whichever way, in whatever situation, it points invariably to primary jurisdiction. It can have validity only if the purpose of primary jurisdiction is to put all litigation involving regulated industries into the exclusive administrative province. But in that case the difficult search for an appropriate test culminates in the disconcerting discovery that tests are superfluous.

Whether adjudication by experts is desirable is not the question. Much can be said for it. But it cannot be achieved without sacrificing other things for which much can likewise be said. To mention one, trial by expert and trial by jury are mutually exclusive. And limitations upon the latter should be effected not by inadvertent encroachment but by constitutional means, or at least by explicit legislative declaration.

\section{Primary Jurisdiction and the Antitrust Laws: The Supersession Theory and the Absence of Administrative Renedy}

Another touchstone than uniformity or expertise has appeared in the area where the antitrust jurisdiction of the courts comes in contact with the regulative jurisdiction of administrative agencies. And a new doctrinal twist-the idea of supersession-has been added to the rule of primary jurisdiction.

The application of the primary jurisdiction rule to antitrust cases is exemplified by United States Navigation Co. v. Cunard Steamship Co. ${ }^{68}$ Here suit was brought against a group of shipping lines to enjoin an alleged combination and conspiracy in violation of the Sherman Act, the crux of the complaint being that the defendants had established a 'dual system of rates, and made the lower rates available to shippers who agreed to use defendants' ships exclusively. Holding that the Shipping Act covered the dominant facts in the case and that "the allegations either constitute direct and basic charges of violations of these [Shipping Act] provisions or are so interrelated with such charges as to be . . . a component part of them," the Supreme Court concluded that "the remedy is that afforded by the Shipping Act, which to that extent supersedes the antitrust laws," and that the "matter, therefore, is within the exclusive preliminary jurisdiction of the Shipping Board."60

The idea of supersession to an extent makes explicit what is often implicit in the rule of primary jurisdiction. For example, where a common law proceeding in the Texas courts was denied in Abilene, the shipper was relegated to a statutory proceeding which had in effect superseded it. But the statutory remedy-reparations granted by the Interstate Commerce Commission, or by

68. 284 U.S. 474 (1932).

69. Id. at 485. This decision was held to be controlling in Far East Conference v. United States, 342 U.S. 570 (1952). For a discussion of the procedural tangles in the FMB-regulated maritime industry, see Note, 64 YALE LJ. 569 (1955). 
the courts after a Commission determination-was equivalent to the shipper's common law remedy of damages. Where the antitrust laws were held to be superseded by another regulatory scheme, however, there might be no remedy under that scheme comparable to what Congress had provided in the antitrust legislation. And so in a number of antitrust suits where the rule of primary jurisdiction has been invoked, the courts have looked to see whether an administrative remedy for the wrong complained of would be available if the rule were applied..$^{\circ 0}$ That is, availability of an administrative remedy is a factor in determining to what extent antitrust jurisdiction remains in the courts or has been superseded by the regulatory commission's jurisdiction. Put another way, availability of an administrative remedy becomes a test of the applicability of the rule of primary jurisdiction.

Georgia v. Pennsylvania R.R. ${ }^{71}$ is an example of the use of the administrative remedy approach. It held to be outside the scope of the rule of primary jurisdiction a suit to restrain a rate-fixing conspiracy. Justice Douglas, speaking for the majority, pointed out that section 16 of the Clayton Act, while authorizing injunctions against violations of the antitrust laws, forbids suits therefor by anyone other than the United States against common carriers in respect of any matter "subject to the regulation, supervision or other jurisdiction of the Interstate Commerce Commission."72 Thus a suit by Georgia to set aside the rates of the defendants resulting from the alleged conspiracy could not have been entertained. ${ }^{73}$ But, said Justice Douglas:

"Georgia in this proceeding is not seeking an injunction against the continuance of any tariff; nor does she seek to have any tariff provision cancelled. She merely asks that the alleged rate-fixing combination and conspiracy among the defendant-carriers be enjoined. . . . But Congress has not given the Commission comparable authority to remove rate-fixing combinations from the prohibitions contained in the anti-trust laws."74

Consequently, this was not a matter "subject to the regulation, supervision, or other jurisdiction" of the Commission, and thus not within the exception of section 16 of the Clayton Act upon which the claim of supersession necessarily rested. This is the context in which the opinion referred to the absence of an administrative remedy. "It must be remembered that this is a suit to dissolve an illegal combination or to confine it to the legitimate area of collaboration. That relief cannot be obtained from the Commission for it has no supervisory authority over the combination."75

70. United States Alkali Ass'n v. United States, 325 U.S. 196 (1945); Georgia v. Pennsylvania R.R., 324 U.S. 439 (1945) ; Slick Airways v. American Airlines, 107 F. Supp. 199 (D.N.J. 1951), appeal dismissed, 204 F.2d 230 (3d Cir.), cert. denied, 346 U.S. 806 (1953); Hawaiian Airlines v. Trans-Pacific Airlines, 78 F. Supp. 1 (D. Hawaii, 1948). See also S. S. W., Inc. v. Air Transport Ass'n, 191 F.2d 658 (D.C. Cir. 1951).

71. 324 U.S. 439 (1945).

72. 38 Stat. 737 (1914), as amended, 15 U.S.C. $\S 26$ (1952).

73. Georgia v. Pennsylvania R.R., 324 U.S. 439, 454 (1945).

74. Id. at $455-56$.

75. Id. at 460 . 
Using the availability of an administrative remedy as a test of applicability of the primary jurisdiction rule is a step in the right direction, for it suggests a responsiveness to the intentions of Congress as regards the relationship between the regulatory statutes and the antitrust laws. And although it would not alone serve as an adequate guide in all cases-it would not have changed the result in Abilene-still because it implies that jurisdiction not conferred upon the regulatory agency is retained by the courts, it would at least prevent the application of the rule of primary jurisdiction to create a jurisdictional vacuum.

\section{The Jurisdictional VacuUn}

The most extreme illustration of the faults of the rule of primary jurisdiction is provided by Montana-Dakota Co. v. Public Service Co ${ }^{76}$ and Seatrain Lines Inc. v. Pennsylvania R.R., ${ }^{77}$ where application of the rule left the plaintiffs without a forum.

In the Montana-Dakota case, defendant and plaintiff's predecessor, while under common management, had interchanged electric energy for which it was alleged defendant paid too little and charged too much. Claiming that the rates were fraudulent and violative of the Federal Power Act's requirement of reasonableness, and that its predecessor had been unable to complain to the Federal Power Commission because of the interlocking directorates, plaintiff sued for damages in a federal district court. The Supreme Court was unanimous in holding that there was no judicial jurisdiction to determine what would have constituted a reasonable rate in the past. ${ }^{78}$

The majority, through Justice Jackson, held that the courts were likewist without jurisdiction of any other question in the case. They rejected plaintiff's claim of "constructive fraud presumed from the intercorporate relationship," saying there could be no such presumption since that relationship had received Commission approval. And, creating a jurisdictional vacuum, they held that the Commission, having no authority to establish a rate retrospectively or to grant reparations, was also without jurisdiction. ${ }^{80}$

Justice Frankfurter wrote the dissenting opinion. Conceding that the Commission could neither award reparations nor fix rates retrospectively, he argued that it could at least advise the court as to what the reasonable rate would have been. He said:

"We think, therefore, that a cause of action within the jurisdiction of the district courts is stated by a complaint charging a distributor of electric energy at wholesale in interstate commerce (1) with buying or selling at unreasonable rates, (2) with failure to comply with procedural requirements of the Federal Power Act, and (3) with preventing others

76. 341 U.S. 246 (1951).

77. 207 F.2d 255 (3d Cir.), cert. denied, 345 U.S. 916 (1953).

78. Montana-Dakota Co. v. Public Service Co., 341 U.S. 246, 251-53 (1951).

79. Id. at 252 .

80. Id. at $252-54$. 
from resorting to the remedies afforded by that Act. In such cases the listrict court should stay proceedings and request determination by the Federal Power Commission of matters within the Commission's special competence."s1

Implicit in the Frankfurter reasoning seems to be the proposition that jurisdiction that the administration agencies cannot exercise should remain in the courts, unaffected by the rule.

The Scatrain case was an antitrust suit in which defendants were charged with concerted action in restraint of trade. Seatrain was a common carrier by water, having ships specially designed to carry loaded freight cars which were delivered to and removed from the docks by railway. After litigation and proceedings before the Interstate Commerce Commission extending over a period of twenty years, Seatrain had procured a Commission order directing the railroads participating in through routes with it to cease and desist from refusing car interchange with it. But railroads not participating in through routes with Seatrain were uniformly refusing to permit car interchange with it although interchanging freely with other railroads. The Commission had conducted an investigation of existing car interchange practices and had found no need for promulgation of rules requiring alteration of interchange practices. But the question of interchange with water carriers in general or with Seatrain in particular was apparently not considered. ${ }^{22}$ And in another proceeding the Commission had held that it was without "jurisdiction to require a rail carrier to permit delivery of its cars to a water carrier where through routes between such rail and water carriers do not exist." 83

Seatrain sued for injunction and damages against the combination of railroads. But the Third Circuit held the rule of primary jurisdiction applicable, saying:

"In this situation Seatrain now asks the federal courts to decide that the present rule of unrestricted car interchange anong the railroads is unlawful unless it shall be so modified and applied as to give Seatrain the same status and privileges as a railroad under it. In other words Seatrain wants the courts to say the railroads may not rightfully do something which the Commission alone is empowered to regulate and control unless they shall in addition do something else which goes beyond the area of Commission concern. Such use of judicial power to condition or require an enlarging modification of an arrangement which is presently effective under Commission jurisdiction and sanction is just such an interference

81. Id. at 264. Emphasis in both the majority and minority opinions on exhaustion of administrative remedies seerns to confuse that rule with primary jurisdiction. Id. at 250, 259.61. Jaffe, Prinnary Iurrisdiction Reconsidered. The Anti-trust Laws, 102 U. PA. L. Rcv. 577, 579 (1954), speaks of primary jurisdiction as involving "at some point a claim enforceable by original judicial action," while under the exhaustion rule "the claim is cnforceable by administrative action alone; the judiciary is being invoked to correct or quash the administrative action."

82. Car-Service, Freight Cars, 268 I.C.C. 687 (1947).

83. Investigation of Seatrain Lines, Inc., 206 I.C.C. 328, 343 (1935). 
with the administrative prerogative as the doctrine of primary jurisdiction is designed to prevent." 84

Montana-Dakota and Seatrain denied a forum to plaintiffs complaining of actionable wrongs and substantial injury. Such a result seems patently wrong. If it is correct to say that primary jurisdiction divests the courts of jurisdiction that is within the administrative sphere then it seems reasonable to suppose that the divestiture should not extend to jurisdiction that existing administrative bodies do not and cannot exercise.

The question in each case was a judicial one. Whether and to what extent a past rate was unreasonable, as in Montana-Dakota, is an issue that courts have long adjudicated, at least in the common carrier field. It should be remembered that in Abilene this jurisdiction was taken from the courts because otherwise there would be interference with the power expressly given to the Commission to make retrospective rate determinations. In Montana-Dakota there was no administrative authority either to make such determination or to award reparations. This certainly justified, if it did not actually make obligatory, a holding that the courts retained jurisdiction to determine the issue with or without administrative advice.

The Seatrain reasoning likewise seems manifestly wrong. The defendants, while freely interchanging cars among themselves, refused to interchange with Seatrain. The Commission had approved the railroad interchange agreement but lacked jurisdiction to approve or disapprove "such defining of the relationship between Seatrain and railroads which do not share through routes with it."

Whether there has been a violation of the antitrust laws is again a judicial question. What interference with the administrative function could result from judicial determination of this question? If the court found in Seatrain's favor it might enjoin further discrimination. This would give the defendants the choice of two courses. They could afford Seatrain the right of interchange, which would leave unchanged that part of the agreement that was subject to Commission jurisdiction. Or they could put an end to free interchange even among themselves. But the Commission, having authority to re-examine the question, could either approve the new practice or order resumption of free interchange. In either case it would be acting independently and without judicial interference. The court would merely have required lawful treatment for Seatrain, something the Commission itself was powerless to do. The important point, seemingly overlooked in the decision, is that regulated industries are subject to continual administrative scrutiny and that the interchange agreement could be ordered modified at any time upon the emergence of a variety of new factors of which the antitrust decision would be only one. Surely, proper regulation would have been furthered rather than impeded by

S4. Seatrain Lines, Inc. v. Pennsylvania R.R., 207 F.2d 255, 258 (3d Cir.), cert. denied, 345 U.S. 916 (1953).

85. Id., 207 F.2d at 261. 
judicial settlement of the antitrust question of which there was no administrative jurisdiction.

The holding that matters beyond administrative jurisdiction may nevertheless be removed from the judicial pale by administrative approval of related matters makes the jurisdictional vacuum inevitable. Unless such a vacuum was specifically intended by Congress in enacting a regulatory law, it should be avoided. Primary jurisdiction must require no more than the rendering to the administrative Caesar of the jurisdiction that Congress intended should be his.

\section{Fragmented Jurisdiction and the Two-Step Remedy}

A vacuum of jurisdiction is not the only pitfall of the primary jurisdiction rule. Even in its less extreme applications it subjects the parties to special inconvenience. For inherent in the rule is fragmentation of jurisdiction.

Why is it called the rule of primary jurisdiction? Presumably, if primary jurisdiction meant original jurisdiction that term of long usage would have been used. But original jurisdiction is complete and the Interstate Commerce Commission's jurisdiction was not. Under the original Act the Commission could issue a reparation order, but that order was not binding upon either the parties or the courts. Only when and to the extent that the order matured into a judgment of the courts could it be enforced. Thus the original jurisdiction of a claim for reparations was fragmented, the Commission functioning as a screen that sifted out and kept from the courts those claims it deemed to be without merit. The cases in which the Commission awarded reparations came to the courts for de novo consideration, the Commission's findings being prima facie but rebuttable evidence.

The 1906 amendment of the Act ${ }^{86}$ made Commission orders-except reparation orders-binding on the parties until set aside by the Commission or the courts. The burden that had theretofore been on the Commission to seek judicial approval of its orders was transformed into the carrier's burden to seek invalidation. But the jurisdiction nevertheless remained fragmented. For if the claimant asked for and received an award of reparations from the Commission the amendment was inapplicable, and the award was not binding without judicial action. And on the other hand, if the claimant came within the amendment by seeking only a determination that a rate, rule or practice had been invalid, he would eventually have to go to the courts to obtain reparations. 87

The expense and delays involved in this two-step procedure have been justifiably criticized. ${ }^{88}$ High costs can put litigation out of the reach of claimants. And it is a truism that justice delayed is often justice denied. To the

86. Act of June 29, 1906, c. 3591, $\$$ 5, 34 Stat. 591-92.

87. Pennsylvania R.R. v. Clark Coal Co., 238 U.S. 456, 471 (1914).

8S. See, e.g., Schwartz, Primary Administrative Jurisdiction and the Exhaustion of Litigants, 41 Geo. L.J. 495 (1953). 
individual of modest means the expense of the two-step procedure may be prohibitive. Courts in cases of this kind have required primary administrative determination of the reasonableness of the cancellation of an airplane flight where damages were sought $;^{89}$ the lawfulness of an airline tariff disclaiming liability for loss of jewelry; $; 90$ and the validity of a tariff requiring notice of claim within thirty days as a prerequisite to a suit for damages for personal injuries or death allegedly due to the carrier's negligence. ${ }^{01}$

Cases such as these point up both the burdensomeness of the two-step procedure and the need to weigh that factor against countervailing considerations in determining applicability of the rule. For it should be kept in mind that fragmentation of jurisdiction is inherent in primary jurisdiction.

\section{Concluston}

The rule of primary jurisdiction ought to serve the necessary purpose of setting the boundaries between the province of the courts and that of the administrative agencies created by Congress, so that the courts do not needlessly interfere with the functions vested in the agencies by Congress. But the rule has not served the purpose well. At its inception it was employed to frustrate the explicitly declared purpose of Congress; in full bloom it has deprived aggrieved parties of any remedy whatsoever, without reference to the purposes of Congress. The trouble has been that the formulas used in the application of the rule-uniformity and expertise-are false guides that can only lead to confusion and misapplication. And since whenever applied it has tended to diminish the scope of jury trial in favor of administrative determination, and to put the plaintiff to a more elaborate and expensive procedure, the rule cries for a sensible touchstone of applicability-one that will pay the price for forfeiture of judicial jurisdiction only when that price has clearly been contemplated by Congress. For since it is Congress that creates the administrative jurisdiction out of which the problem of conflicting jurisidictions originates, it is in congressional intent that the problem's solution should be found.

The really germane subject for inquiry, then, is the kind and scope of the regulation delegated by the governing act; and the test question is whether initial judicial determination of a given issue will interfere with administrative regulation. The answers will not be the same under all acts or with respect to all regulated industries. The regulatory power of the Interstate Commerce Commission differs in kind and scope from that of the Federal Power Com-

89. Adler v. Chicago \& So. Air Lines, Inc., 41 F. Supp. 366 (E.D. Mo. 1941).

90. Lichten v. Eastern Airlines, Inc., 189 F.2d 939 (2d Cir. 1951).

91. In re Continental Charters, Inc., 3 PIKE \& Fischer Ad. L. Dec. (2d ser.) 130 (CAB 1953). In the unreported district court case the question of the lawfulness of the tariff was held to be within the primary jurisdiction of the Board. But sec Thomas v. American Airlines, Inc., 104 F. Supp. 650 (E.D. Ark. 1952) (tariff ineffective as disclaimer of liability for negligence) ; Glenn v. Compania Cubana de Aviacion, 102 F. Supp. 631 (S.D. Fla. 1952) (tariff ineffective as a defense to wrongful death action); Wilhelmy $v$. Northwest Airlines, 86 F. Supp. 565 (W.D. Wash. 1949) (tariff held lawful). 
mission. Similarly, the Interstate Commerce Commission's supervisory power over railroads differs from its power over oil pipe lines. Consequently, in a similar state of facts, primary jurisdiction may be appropriate for one industry and altogether inappropriate for another. Obviously, what is required is not an indiscriminate but a selective application of the rule, attainable only by the test of legislative intent.

This test would bring all primary jurisdiction cases, within and without the antitrust field, into harmony, for whether the antitrust laws have been superseded is a question of statutory purpose. It should also help to eliminate the jurisdictional vacuum. Judicial exercise of initial jurisdiction of a matter that is not within the administrative scope is not likely to run counter to the statutory scheme of regulation. Moreover, this test puts primary jurisdiction in its proper perspective. The essential purpose of the rule is to define the borders of judicial and administrative jurisdiction. Since, but for the rule, the issue would be one for the courts, that definition must be derived from the nature and extent of the authority to regulate. Finally, abandonment of such cliches as uniformity and expertise-will serve the salutory purpose of clearing the air. And supplanting them with a test under which jurisdiction turns upon the kind and extent of the regulation prescribed by Congress will contribute to the equally desirable result of keeping judicial construction in harmony with legislative purpose. 


\section{THE YALE LAW JOURNAL}

\begin{tabular}{llr}
\hline VoluMe 65 & JANUARY, 1956 & Number 3 \\
\hline
\end{tabular}

\section{EDITORIAL BOARD \\ Norbert A. SchleI \\ Editor-ir-Chief}

\author{
David B. IsBelL \\ Article and \\ Book Review Editor
}

IrVing J. Alter

BENJAMIN $\mathrm{H}$. BALKIND

MaLvin E. BanK

JOHN W. BARNUM

AXEL H. BAUM

MELVIN L. BEDRICK

C. WiLliam Berger

DANIEL M. BERGER

NEIL N. BERNSTEIN

Robert W. BlanceEtTe

JUDITH MYRA BIEICH

JaMies $H$. Bratton, JR.

ALAN P. ColodNy

EDMUUND V. CONWAY

J. RICHARD DUFFIELD

H. EDW. DUNKELBERGER, JR.

RODNEY E. EYSTER

\author{
Gerald M. Doppelt \\ JoN O. NEWMAN \\ RICHARD H. PERSHAN \\ Note and Comment Editors
}

\author{
GERALD T. Flom \\ Alvin Friedaran \\ VICTOR S. FrIEDMIAN \\ Morton I. Greenberg \\ Milmon S. GwirTZMaN \\ ROBERT J. HARRIS \\ Grorge C. Hastings \\ IRA Míchaed HeyaraN \\ Bud George Holatan \\ WILLIAas E. Huth \\ Charles D. IsaAC \\ LLOYD J. KENO \\ LAWRENCE R. KLEIN \\ DAVID KLINGSBERG \\ HAROLD S. LEVY \\ IRWIN A. LEVY \\ JULIUS LEWIS \\ ARTHUR L. LIMAN
}

\author{
Stephen J. Pollak \\ Managing Editor
}

Barbara A. LindeMAanN

Ralph C. Mínapace, Jr.

Edward A. Miller

Otis P. Pearsall

ROBERT S. REDMOUNT

Marvin N. Rimar

BERNARD S. RobBINS

Ray MaURy Shainderg

WALTER E. SHUTTLEWORTH

ROBERT J. SISK

ARLEN SPECTER

JOHN T. SUBAK

Charles $W$. Thomiasson

Charles H. Vetvoda

FRANK E. G. WEIL

STEPHEN A. WEINER

HOWARD P. WILLENS

Marie McMahon

Business Secretary

\section{CONTRIBUTORS TO THIS ISSUE}

Albert A. Ehrenzweig. Dr. Jur. 1928, Vienna University; J.D. 1941, University of Chicago; LL.M. 1942, J.S.D. 1952, Columbia University. Professor of Law, University of California, Berkeley. Author: Mistake and Unlawfulness (1931); ToRT Linbility for FaUlt (1936); A NEW LAW of Torts (1937) (in German); Income Tax Treatres (1950) ; Negligence Without Fatit (1951); "Full Aid" Insurance for the Traffic Victim-A Voluntary Compensation Plan (1954).

Israel Convisser. LL.B. 1928, Brooklyn Law School. Member of the District of Columbia and New York Bars. 